\title{
Evaluation of drying temperature and storage time on the water content, aroma and taste of lemon pepper (Zanthoxylum acanthopodium DC.) powder
}

\author{
Erika Pardede ${ }^{1^{*}}$, Ferlando J. Simanungkalit ${ }^{1}$, and Johan B. Manik ${ }^{2}$ \\ ${ }^{1}$ Department of Agricultural Product Technology, University of HKBP Nommensen, 20234, Medan, \\ North Sumatera, Indonesia \\ ${ }^{2}$ Alumni of Dept. of Agricultural Product Technology, University of HKBP Nommensen, 20234, \\ Medan, North Sumatera, Indonesia
}

\begin{abstract}
The fruits lemon pepper (Zanthoxylum acanthopodium DC.) are commonly used as flavouring in fresh form. Meanwhile, the lemon pepper fruits are perishable and easily attacked by fungi and loss its colour and fragrance. In this study, during a 4-week storage, the effects of drying temperature $\left(40,50,60\right.$ and $\left.70^{\circ} \mathrm{C}\right)$ in a hot oven on water content, aroma and taste intensity of lemon pepper powder were evaluated. The initial average moisture content of fresh lemon pepper is $68,5 \%$. Among the four drying temperature that were used, $40{ }^{\circ} \mathrm{C}$ and $70{ }^{\circ} \mathrm{C}$ showed no significant different effect on water content, while $50{ }^{\circ} \mathrm{C}$ and $60{ }^{\circ} \mathrm{C}$ produced a lower water content. The intensity of the aroma and taste of lemon pepper decreases significantly with the increase of drying temperature. The moisture content, aroma and taste intensity were also decreased significantly during the experimental storage period (4 weeks). Our experiment has shown that lemon pepper powder dried at $40{ }^{\circ} \mathrm{C}$ has a lower water content and can maintain aroma and taste better than lemon pepper dried at $50-70{ }^{\circ} \mathrm{C}$ in a hot air oven. Therefore, the drying temperature of $40^{\circ} \mathrm{C}$ is a better option for drying lemon pepper.
\end{abstract}

\section{Introduction}

The lemon pepper (Zanthoxylum acanthopodium DC.) fruit in fresh form is often used as an herb to give extraordinary flavor to foods and as a flavor enhancer because it produces a spicy, bitter and burning taste when eaten. There are some examples of the usage of the fruits in some traditional Batak's dishes such as naniarsik, naniura, and napinadar.

The flavor of the herbs was contributed by the essential oils in the cell wall of the plants, which released during chopping and grinding [1]. The essential oil composed of many chemical compounds, which $90-95 \%$ were volatile, which belong to various chemical classes: alcohols, ethers or oxides, aldehydes, ketones, esters, amines, amides, phenols, heterocycles, and mainly the terpenes. Some herbs contained more than a hundred chemical

\footnotetext{
* corresponding author: erikalrp@yahoo.de
} 
compounds, where each contributed to the overall flavor of herbs [2]. Moektiwardoyo et al. (2014) identified 29 compounds in the essential oil of lemon pepper's fruits. Amongst them, geranyl acetate, $\beta$-citronelol, nerol, limonene, geraniol, caryophyllene, citronellyl acetate and $\alpha$-pinene were the predominant compound of the fruit oil, which contributed to the aroma of lemon pepper [3].

High moisture content in fresh agricultural and food products is the main reason for the destruction of the material after microbial growth and biochemical reactions. The basic principle of drying as the oldest methods of food preservation is to remove water from the material up to the level at which microbial spoilage and deterioration reactions are highly minimized therefore prevents deterioration within a certain period of time, and hence increasing shelf life of products [4]. Nonetheless, this drying preservation technique has disadvantages and limitations. Prusinowska and Śmigielski (2015) indicated that the drying process affects the losses of essential oils and antioxidant in herbs and spices [5]. The contact between the dried material and hot air causes degradation of key flavor compounds and nutritional substances, and there is a risk of volatilization of volatile compounds throughout the drying operation [6]. There were many factors which affect the loss of volatile compounds during the drying process, such as method of drying [1], drying temperature [6-8], and the interaction between the volatile compounds and water vapor, as well as hydrophobicity of the volatile compounds [9].

During storage, the loss of flavor was progressed beside the spoilage by the mold attack [10]. The essential oils of lemon verbena (Lippia citriodora Kunth.) [11], Thymus daenensis Celak [12] were decreased with extended storage period. However, properly stored herbs can effectively preserve herbs up to one year in a cool, dry, and dark place. Storage in dried powder form offered easy handling and storage before processing for several uses [10].

The main objective of this experiment was to investigate the effect of drying temperature $\left(40,50,60\right.$ and $\left.70^{\circ} \mathrm{C}\right)$ in a hot oven drying on water content, intensity of aroma and taste of lemon pepper powder during 4 weeks storage.

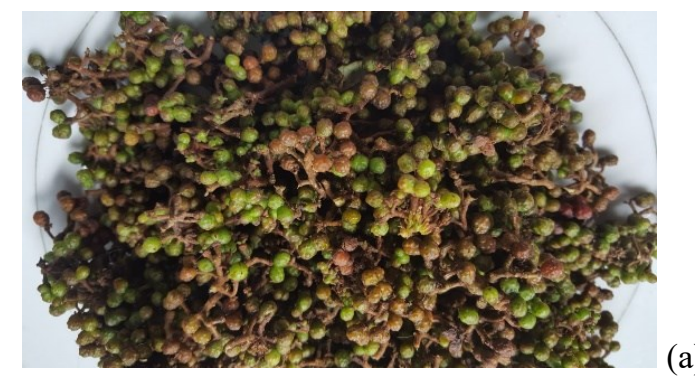

(a)

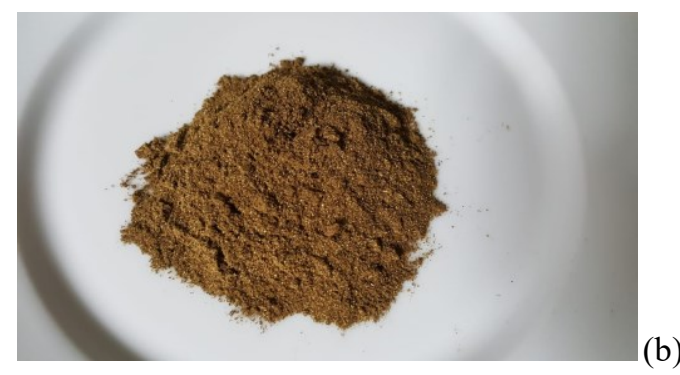

Fig. 1. (a) Fresh lemon pepper; (b) Lemon pepper powder. 


\section{Materials and methods}

Fresh lemon pepper fruits were purchased from local suppliers and directly brought to Laboratory of Agriculture Products Technology, University of HKBP Nommensen, Medan, where this study was conducted. Lemon pepper fruits were sorted manually as to separate fruits from dirt, leaves and stems. Then they were washed and drained.

The sample, then, was divided into 4 parts. Each of them was dried using a convection oven at four different temperatures $\left(40,50,60\right.$ and $\left.70{ }^{\circ} \mathrm{C}\right)$. Dried fruits were grounded and followed by sieving through 80 -mesh sieve. The lemon pepper powder was packed directly after sieving in polyethylene zipper plastic bags and stored in a cool and dry place at room temperature away from direct light for 4 weeks.

The moisture content (on a wet basis) as well as aroma and taste intensity were determined for all samples every week for 4 weeks. Measurement of water content was done according to the weight loss of the samples which were dried by heating. The intensity of the aroma and taste were determined using sensory analysis method, and employed a 5scale intensity test. The aroma and taste intensity of fresh squeezed fresh lemon pepper fruit were used as a reference for the intensity value of 5 both for aroma and taste. This experiment was conducted using 10 trained panellists.

\section{Result and discussion}

The dry powder of lemon pepper was characterized by a brown colour (Fig. 1b). The darkening of the colour of dried sample could be due to temperature during dehydration in addition to black colour of the lemon pepper seeds. The observed values of the water content, intensity of aroma and taste showed significant differences depending on the drying temperature used (Figure 2, 3 and 4).

\subsection{Water content}

From the average initial moisture content of $68,5 \%$ in fresh fruits to achieve the equilibrium moisture content needs $6 \mathrm{~h}$. Moisture is the water content that remains inside the cell once the extracellular water clears away by drying. The moisture content of lemon pepper powder was decreased significantly different with the increasing of drying temperature. The moisture contents of the lemon pepper powder which were obtained by drying at 40, 50, 60 and $70{ }^{\circ} \mathrm{C}$ as were $17.24 \%, 14.50 \%, 13.30 \%$ and $17.24 \%$ respectively.

Higher drying temperature led to a significantly lower water content. However, it was true until the dry temperature of $60{ }^{\circ} \mathrm{C}$. At the level of $70{ }^{\circ} \mathrm{C}$ the water content was not significantly different from water content of powder dried at $40{ }^{\circ} \mathrm{C}$. A possible explanation for this might be that the case hardening took place at temperature above $60{ }^{\circ} \mathrm{C}$ and led to a higher amount of water retained in the fruit during drying time.

Figure (2) shows the degree of water content change during storage at room temperature. After one week in storage, the water content of lemon pepper powder, dried at 40 and $70{ }^{\circ} \mathrm{C}$ decrease significantly. They reached the level of water content of powder, dried at 50 and $60{ }^{\circ} \mathrm{C}$. During the following weeks of storage, water content all samples increase slightly at the end of 4 weeks of storage and reached the level of $11.32 \%, 12.39 \%$, $12.26 \%$ and $12.87 \%$ of samples dried at $40,50,60$ and $70{ }^{\circ} \mathrm{C}$ respectively. This unique phenomenon might be due to the movement of the water either adsorb or desorb into the samples during the storage process, which were also known as adsorption isotherm and desorption isotherm. Razak et al. (2020) found that the moisture content of ground powder was radically affected by initial moisture content. The moisture content of samples with high initial moisture content was decreased throughout the storage time, whereas, moisture 
content of samples with low initial moisture content had significantly increased during storage [7]. Normally, the equilibrium moisture content will be achieved when the moisture content in the stored samples is consistent.

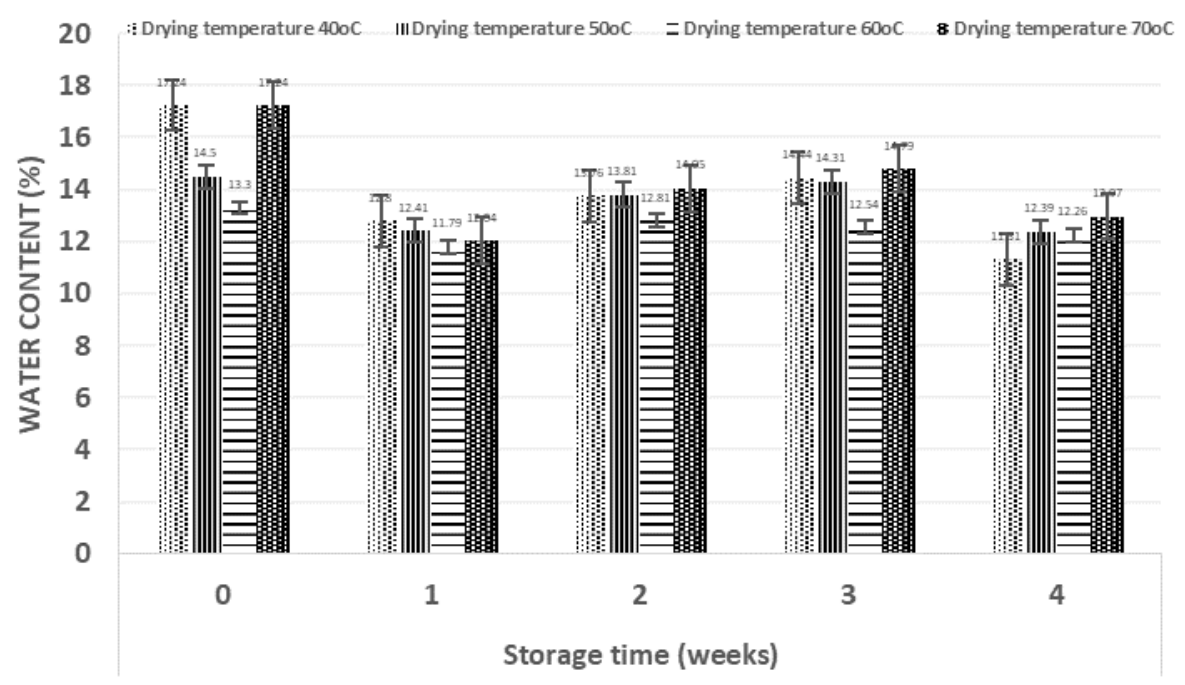

Fig. 2. Water content of the lemon pepper powder during 4 weeks of storage.

Appropriate moisture content in the lemon pepper powder is necessary to avoid microbial growth and prevent product degradation. Therefore, low moisture contents are recommended. Using the Indonesian National Standard (SNI) as standard, that the maximum water content is $14 \%$ of black pepper powder, therefore it was recognized that all sample fitted to the national standard by the end of 4 weeks of storage [13].

\subsection{Aroma and taste}

Here in this study, the intensity of both aroma and taste lemon pepper powder were evaluated by using the aroma and taste of fresh squeezed fresh lemon pepper fruit as a reference to the highest intensity (scale value of 5).

Figure (3) and (4) shows that native aromas of lemon pepper were well retained when drying process took place at a temperature of 40,50 and $60{ }^{\circ} \mathrm{C}$, with scale values of 5,0 ; 5,0 ; and 4,95 respectively. However, at higher temperature $\left(70^{\circ} \mathrm{C}\right)$ there was a slight loss of aroma with the scale value of 4,6. One of many factors which affect the loss of volatile compounds was the drying temperature. Apply high drying temperature could lead to higher loss of volatile compounds as high temperature could promote degradation of the heat labile compounds which composed essential oil [1]. This study was agreeing with the finding of Silva et al. (2017) which reported that an increase in air temperature during dying had statistically negative effect on the monoterpene content of essential oil from $S$. terebinthi-folius fruits. Beigi et al. (2018) also reported that essential oil content of dried leaves was decreased with the increasing of drying temperature by hot air dryer $[6 ; 8]$

The similar trend on the aroma was also found on taste of lemon pepper. In other words, the loss of aroma and taste of lemon pepper was related to temperature, and indicated that temperature above $60{ }^{\circ} \mathrm{C}$ could lead to removal of essential oils, thereby lemon pepper loses its fragrance. Samples dried at $40{ }^{\circ} \mathrm{C}$ loss their intensity of aroma and taste than samples 
dried at higher temperatures. Similarly, less water loss was also found on sample dried at 40 ${ }^{\circ} \mathrm{C}$. Loss of volatile concentration was also strongly associated with the amount of water being evaporated, as reported by Antal at al. (2011) that water acts as a solvent which enabling the diffusion of volatile compounds within the dried material, and water vapor acts as a carrier that enhances the transfer of volatiles from the material being dried to the surroundings [9]. This experiment shows that independent from the storage factor, the lower drying lemon pepper at temperature range from 40 to $60{ }^{\circ} \mathrm{C}$ retains the aroma and taste better, meanwhile, the finding of Napitupulu et al. (2020) that oven drying at the $54{ }^{\circ} \mathrm{C}$ for $8 \mathrm{~h}$ was the most appropriate processing method to preserve the flavour of lemon pepper [14].

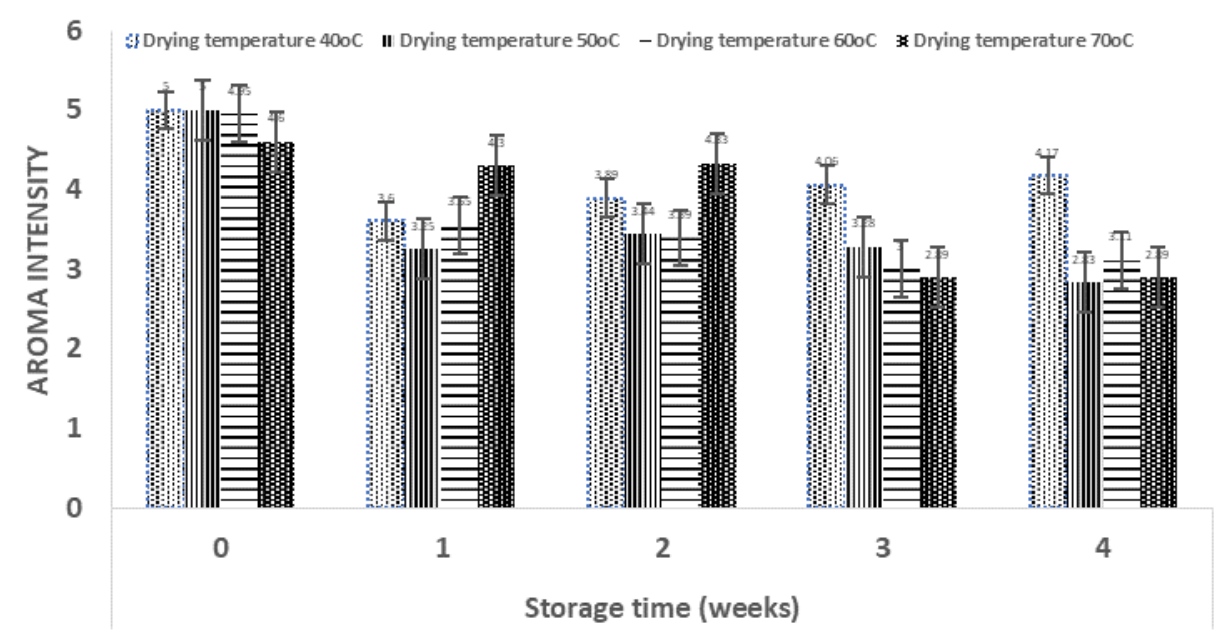

Fig. 3. Aroma intensity of lemon pepper powder during 4 weeks of storage.

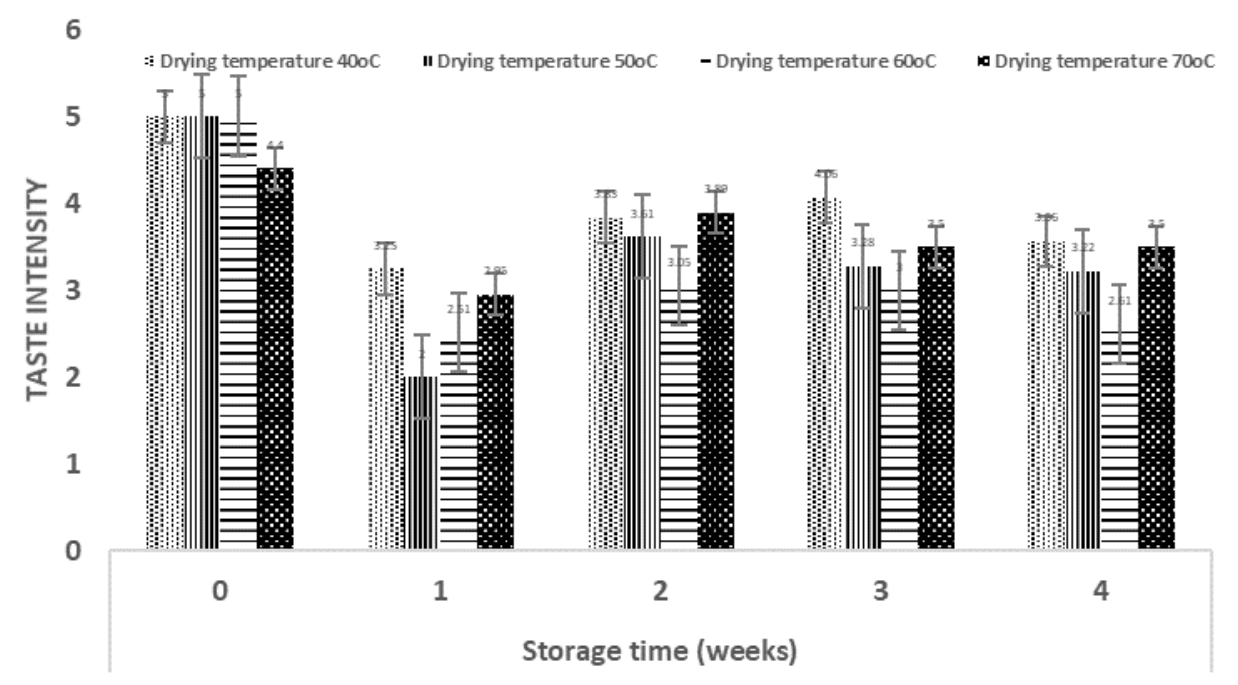

Fig. 4. Taste intensity of lemon pepper powder during 4 weeks of storage. 
Figure (3) and (4) show that all lemon pepper powder displayed decreasing of the intensity of the aroma during 4 weeks of storage at room temperature. The intensity of the taste showed different pattern, as at the first week of storage the intensity of the taste decrease, followed by the increasing up to the value scale of $3-4$ which then remained at the same level until the end of 4 weeks of storage. Prior to storage, the aroma and taste intensity of powders which were dried at 40,50 and $60{ }^{\circ} \mathrm{C}$ were higher than the ones dried at $70{ }^{\circ} \mathrm{C}$, however, only the aroma and taste intensity of samples dried at $40{ }^{\circ} \mathrm{C}$ was remain higher after the 4 weeks of storage. The similar effect was reported in dried Satureja hortensis cv Saturn by which researchers proposed reasons such as the continued release of essential oil from the plant matrix [15]. Another reason for reducing some component of essential oil was penetration of some volatile compound into packaging material [16]. Therefore, the authors suggested that drying at the temperatures of $40 \circ \mathrm{C}$ can be considered as an optimal compromise in the quality of lemon pepper powder; under these temperature conditions, the acceptable water content, the better aroma and taste intensity are achievable for 4 weeks of storage.

\section{Conclusions}

The drying temperature and the storage period have significant effects on the water content, the intensity of aroma and taste lemon pepper powder. The higher drying temperature causes greater water loss; however, it was not happening when the drying took place at 70 ${ }^{\circ} \mathrm{C}$. There were also significant decreases of aroma and taste during the storage period, while the water content decreases significantly during the first week of storage and increase slightly over the following time. Based on this experiment authors suggest that the drying at temperatures of $40^{\circ} \mathrm{C}$ can be considered as an optimal compromise in the quality of lemon pepper powder; under these temperature conditions, the acceptable water content, better aroma and taste intensity are achieved for 4 weeks of storage.

The authors thank The University of HKBP Nommensen for financial support.

\section{References}

1. G. Thamkaew, I. Sjöholm and F. G. Galindo, Critical Reviews in Food Science and Nutrition 61(11): 1763-1786 (2021), DOI: 10.1080/10408398.2020.1765309

2. W. Dhifi, S. Bellili, S. Jazi, N. Bahloul, W. Mnif. Medicines 3 (25): 1-16. (2016) DOI:10.3390/medicines3040025

3. M. Moektiwardoyo, M. Muchtaridi, and E. Halimah. Int. Jour. of Pharmacy and Pharmaceutical Sci. 6 (2): 547-555 (2014)

4. A. Calín-Sánchez, L. Lipan, M. Cano-Lamadrid, A. Kharaghani, K. Masztalerz, A. Carbonell-Barrachina and A. Figiel. Foods 9: 1-27. (2020) DOI:10.3390/foods9091261. DOI:10.3390/foods9091261

5. R. Prusinowska and K. Śmigielski. Nauki Inżynierskie I Technologie: Engineering sciences and technologies 17(2): 51-62 (2015) DOI: 10.15611/nit.2015.2.05

6. B. G. Silva, A. M. F. Fileti, M. A. Foglio, P. T. V. Rosa, O. P. Taranto. Journal of Food Quality Vol. 2017:1-12. (2017) DOI: 10.1155/2017/3152797

7. N. A. Razak, A. R. Razak, A. Shaari, N. Felixanak, S. Simbas, S. Abdullah. Int. Jour. of Agric. Innov. and Res. 2(6):2319-1473 (2014)

8. M. Beigi, M. Torki-Harchegani, and A. G. Pirbalouti. International Journal of Food Properties 21(1): 267-276 (2018). DOI:10.1080/10942912.2018.1453839. 
9. T. Antal, A. Figiel, B. Kerekes, L. Sikolya. Drying Technology 29:1836-1844. (2011) DOI: 10.1080/07373937.2011.606519.

10. C. F. Lisboa, E. de Castro Melo and S. M. L. Donzoles. Biomed Jour. of Sci. \& Tech. Res. 4 (4): 4093-4095 (2018). DOI: 10.26717/BJSTR.2018.04.0001097.

11. M. Ebadi, F. Sefidkon, M. Azizi, N. Ahmadi. Food Science \& Nutrition. 2017 (5): 588595 (2016). DOI: 10.1002/fsn3.434.

12. V. Rowshan, A. Bahmanzadegan, M. Saharkhiz, Mohammad. Crops and Products. 49 (2013): 97-101. (2013). DOI: 10.1016/j.indcrop.2013.04.029.

13. BSN (Badan Standar Nasional). 1995. SNI 01-3716-1995 Lada Hitam Bubuk. Badan Standardisasi Indonesia.

14. F. I. R. Napitupulu, C. H. Wijaya, Sulistiyani, E. Pangdimurti, C. Akyla, L. A. Yakhin and S. Indriyani. J. Eng. Technol. Sci. 52(3):399-412 (2020)

15. S. Mohtashani, M. Balabar, L. Tabrizi, A. Ghani, Rowshan, V. and M. Shokrpour. Food Sci. Nutr. 2021:1-12 (2021) (Open access) DOI: 10.1002/fsn3.2451

16. M. Chaliha, A. Cusack, M. Currie, Y. Sultanbawa, and H. Smyth. J. Agric. Food Chem. 24(61): 5738-5745 (2013). DOI: 10.1021/jf400845t 